\title{
Growth Hormone Releasing Hexapeptide-6 (GHRP-6): Possible Protective Role against Experimentally-Induced Osteoporosis in Female Albino Rats
}

\author{
Ibrahim Y. Ibrahim, Walaa H. Nazmy, Adel H. Saad and \\ El-Shymaa A. Abdel-Hakeem \\ Department of Physiology, Faculty of Medicine, Minia University
}

\begin{abstract}
Postmenopausal osteoporosis is by far the most common cause of age related bone loss. Growth hormone (GH) is not only important for linear body growth during childhood, but it is also a major determinant of adult bone mass. GH secretion diminishes with aging. Therefore, there might be a causal link between the agerelated decline in GH secretion and bone loss after menopause. So, the present study was designed to investigate the effect of growth hormone releasing hexapeptide (GHRP-6), a synthetic GH secretagogue, on bone loss in ovariectomized albino rats and to compare the results with those of estrogen replacement therapy as a strategy for treatment in such condition. All rats (except the control rats) were subjected to bilateral ovariectomy and were divided into four groups (10 rats each): sham operated control, ovariectomized (OVX), OVX+ estrogen supplemented and OVX+GHRP-6 treated groups. Rats were administrated their treatments subcutaneously daily for 6 weeks. In the present study, GHRP-6 was equally powerful as estrogen in preventing OVX-induced bone loss. Even more, it caused a +ve shift between bone resorption and bone formation for the benefit of bone formation as evidenced by the higher serum levels of alkaline phosphatase (a marker of bone formation) without any significant change in acid phosphatase level (a marker of bone resorption). In conclusion, GHRP-6 prevents ovariectomy-induced bone loss in albino rats mainly via preservation of bone tissue and increasing bone formation. Hence, GHRP-6 could be of value for postmenopausal osteoporotic women who cannot tolerate estrogens or for whom estrogens are contraindicated.
\end{abstract}

Keywords: GHRP-6, ovariectomy, osteoporosis, estrogen, rats

\section{INTRODUCTION}

Bone is a dynamically metabolized connective tissue which is maintained by a balance between bone formation and bone resorption being regulated by hormonal and physical factors ${ }^{[1]}$. After menopause, that balance is disrupted and the rate of bone loss is faster than its rebuilt ${ }^{[2,3]}$. Therefore, aging women are susceptible to bone loss known as post- menopausal osteoporosis $^{[4]}$.

Postmenopausal Osteoporosis is a major health problem with significant morbidity and mortality ${ }^{[\mathbf{5 , 4 , 6}]}$ especially with increasing numbers of postmenopausal women allover the world $^{[7]}$. 
OVX rats have been widely used as an animal model for studying the prevention and treatment of postmenopausal osteoporosis because of the similarities observed between OVX-induced bone loss in rats and postmenopausal bone loss in humans $^{[7,8]}$. Therefore, that model of experimental osteoporosis was chosen in the present study.

Several pharmacological agents are available for prevention and treatment of osteoporosis; two main classes are used, antiresorptive and anabolic agents. Estrogen (antiresorptive drug) is the most widely used replacement therapy for prevention of osteoporosis ${ }^{[9]}$ however; estrogen use and compliance are limited due to its numerous undesirable side effects such as uterine and breast cancer ${ }^{[10]}$. Therefore, there is a significant medical need for a therapy that protects against postmenopausal bone loss with much lower side effects compared to those of estrogen and others available in the market ${ }^{[11]}$.

The GH/insulin-like growth factor1 axis is not only important for linear body growth during childhood, but it is also one of the major determinants of adult bone mass ${ }^{[12]}$. Previous studies have shown that adult onset GH deficiency (GHD) is associated with a lower bone mass and increased frequency of osteoporotic fractures, at least in women ${ }^{[13]}$. Others have shown that $\mathrm{GH}$ treatment increases bone mass in rodents as well as in humans $^{[14,15]}$. Furthermore, GH secretion and $\mathrm{GH}$ dependent serum insulin-like growth factor-I (IGF-I) levels diminish with increasing age ${ }^{[13]}$. Therefore, further research is required to clarify the link between diminished $\mathrm{GH}$ secretion and bone loss in aging postmenopausal women.

GHRP-6 is a member of $\mathrm{GH}$ secretagogues (GHSs) which are potent stimulators of $\mathrm{GH}$ release ${ }^{[\mathbf{1 6 ]}}$. However, a limited number of studies have shown its potential role in bone tissue. Therefore, the aim of the present study was to evaluate the effect of GHRP-6 on bone loss in OVX albino rats (as an experimental model of postmenopausal osteoporosis) and to compare the results with those of estrogen replacement therapy as a line of treatment in such condition.

\section{MATERIALS \& METHODS}

\section{Animals:}

Forty adult female albino rats from local strain (150-250 grams; obtained from the Animal House, Faculty of Medicine, Minia University) were used in the present study. Rats were housed at room temperature with normal dark/light cycles. The rats were fed a standard diet of commercial rat chow and tap water ad libitum and left to acclimatize to the environment for two weeks prior to inclusion in the experiment ${ }^{[17]}$. All experimental procedures were performed according to the institutional guidelines of Minia University.

\section{Experimental procedures \\ Induction of experimental osteoporosis:}

All rats (except for control group) were bilaterally ovariectomized under light ether anesthesia. In a glass hood saturated with ether vapor, rats were placed to inhale ether until the 
surgical stage of anesthesia was reached (judged by loss of withdrawal reflexes), rats were then removed and placed on the operating board for ovariectomy as previously described $^{[18]}$.

Briefly, under clean aseptic conditions and after shaving the hair of the lower abdomen, a single longitudinal skin incision was made in the midline of abdominal wall above symphysis pubis. The skin was retracted laterally and the abdominal wall and the peritoneum were incised. The ovarian fat pad was pulled out to locate the ovary and oviduct. A hemostat was placed on the oviduct just proximal to the ovary, then a ligature with absorbable cut gut was done and the ovary was excised and the procedure was repeated on the other side. Finally, the incision was closed in two layers with absorbable sutures and the rat was observed until the recovery from anesthesia. Histological sections were used to assess ovariectomy. The same surgical procedures were done in the sham operated control group except removal of the ovaries.

\section{Experimental groups:}

Following operation, rats were randomly divided into the following groups (10 rats each):

(i)Control sham operated group (C); in which rats were left freely wandering in their cages and received no medication throughout the period of the experiment.

(ii)Ovariectomized group (OVX); in which rats were subjected to bilateral ovariectomy $^{[2]}$.

(iii)OVX-estrogen treated group $(\mathrm{OVX}+\mathrm{E})$; in which each rat was injected subcutaneously with
$30 \mu \mathrm{g} / \mathrm{kg} /$ day of estradiol benzoate for 6 weeks immediately after ovariectomy $^{[19]}$. Estradiol benzoate was obtained as ampoules containing $5 \mathrm{mg} / \mathrm{ml}$ (Folone; Misr Co. For Pharm. Ind. S.A.E.).

(iv) OVX-GHRP-6 treated group; in which each rat was injected subcutaneously with 0.5 $\mathrm{mg} / \mathrm{Kg} /$ day of GHRP-6 for 6 weeks immediately after ovariectomy $^{[15]}$. GHRP-6 was obtained as vials containing $5 \mathrm{mg}$ / $\mathrm{ml}$ (Bachem, Bubendorf, Switzerland).

At the end of the experiment, rats were sacrificed, blood samples were collected from jugular vein, allowed to clot, centrifuged for 20 minutes (3000 rpm) and serum obtained was stored at $-20^{\circ} \mathrm{C}$ for further determination of serum calcium, phosphorus and bone turnover markers (alkaline and acid phosphatases) levels. The right femurs of all rats were excised and were used for determination of bone parameters (mass, density and mineral content).

\subsection{Serum parameters:}

\section{Determination of calcium level:}

In the present study, serum calcium level was measured using serum calcium assay kit (Greiner Diagnostic GmbH, BahlingenGermany) according to (Ocresolphthalein complex one colorimetric method). It depends on the reaction of calcium ions with $\mathrm{O}$ cresolphthalein complex one (O-CPC) to form a violet colored complex, the intensity of which is directly proportional to the calcium concentration and the absorbance was determined at $565 \mathrm{~nm}$ using a spectrophotometer (Spectronic 2000; 
Bausch \& Lomb, Rochester, NY, USA) ${ }^{[20]}$.

Determination of phosphorus level:

Serum phosphorus level was measured using serum phosphorus assay kit (Greiner Diagnostic $\mathrm{GmbH}$, Bahlingen- Germany) depending on the reaction of inorganic phosphorus with ammonium molybdate in an acid medium to form a phosphomolybdate complex, which absorbs light at 340 nm. The absorbance at that wave length is directly proportional to the amount of inorganic phosphorus present in the sample ${ }^{[21]}$.

Determination of Alkaline
phosphatase (ALP) and acid
phosphatase (ACP) levels:

Both serum levels of ALP and ACP were measured colorimetrically using ALP assay kit (Spectrum, Egyptian Company for Biotechnology, Egypt) and ACP assay kit (Biodiagnostic, Egyptian Company for Biotechnology, Egypt). It depends on alkaline or acid hydrolysis of phenylphosphate by either ALP or ACP to release phenol which complexes with 4-aminoantipyrine and 4-aminophenazone to produce a colored complex, the intensity of which can be assessed colorimetrically to reflect each enzyme concentration respectively ${ }^{\text {[22, }}$ 23].

\section{Bone preparation and parameters:}

The right hind limb of each rat was finely dissected and the right femur was removed, cleaned from adhering soft tissue. All femurs were first weighed in the presence of air (W), then reweighed while suspended in water (WW) at room temperature using "a Sartorius balance". The difference between the two weights
(W-WW) was equivalent to the volume of the bone ${ }^{[24]}$.

Bone density (Archimedes' principle):

It is the standard method for determination of density $\left(\mathrm{g} / \mathrm{cm}^{3}\right)$ of bones from small animals using the formula:

$$
\text { Density }=\frac{w}{w-w w} x p
$$

Where, $\mathrm{P}$ is the density of distilled water at room temperature ${ }^{[25]}$.

\section{Preparation of dried femurs:}

For dry bone preparation, the right femurs were first dried to constant weight at $100^{\circ} \mathrm{C}$ for $24 \mathrm{~h}$ and reweighed for the determination of dry weight (DW) which includes organic, mineral, and fat as the water content was only evaporated. On the basis of the obtained initial weight of femur in air (W) and the dry weight (DW), the weight of water content in the femurs was calculated using the formula: $\mathrm{W}_{\text {water }}=\mathrm{W}-\mathrm{DW}$, and the percentage of water content $=\mathrm{W}_{\text {water }}$ $\times 100 / \mathrm{W}^{[26]}$.

Preparation of fat-free dry femurs (FFDFs):

FFDFs were determined according to the method described by Watkins and Southern ${ }^{[27]}$. The right femurs were extracted for $48 \mathrm{hs}$ in $90 \%$ petroleum ether and were dried in a forced-air oven at $90^{\circ} \mathrm{C}$ until constant weight was obtained.

Preparation of femurs ash: The bone ash weight (AW) which contains only the mineral was obtained after ashing at $600{ }^{\circ} \mathrm{C}$ for $24 \mathrm{hs}^{[28]}$. Briefly, concentrated nitric acid $(0.1 \mathrm{ml})$ and $30 \%$ hydrogen peroxide $(0.05 \mathrm{ml})$ were added to each sample and then placed in a sand bath heated at $600{ }^{\circ} \mathrm{C}$. That treatment was repeated until a 
whitish residue was obtained. The residue was dissolved in $1 \mathrm{ml} \mathrm{HCl}$ and $10 \mathrm{ml}$ distilled deionized water ${ }^{[29]}$ to measure the calcium and phosphate concentrations spectrophotometry $^{[30]}$.

On the basis of the previously obtained weights (W, DW, and AW), the following calculations were $\operatorname{made}^{[26]}$ :

-Percentage of non-organic components: Weight of non organic component $=$ ash weight.

$\%$ of non- organic component $=$

$\mathrm{W}$ non-org. comp. $\times 100 / \mathrm{W})$

-Percentage of organic components:

$\mathrm{W}$ org. comp. $=\mathrm{DW}-\mathrm{AW}$

$\%$ of organic components $=$

$\mathrm{W}_{\text {org. comp. }} \times 100 / \mathrm{W}$ )

\section{STATISTICAL ANALYSIS:}

All data were expressed as means \pm standard errors (mean \pm SEM). Data were analyzed using one-way analysis of variance (ANOVA) with repeated measurements. All the statistical analyses were performed using general linear model procedure (SAS Institute Inc., NC, USA, 2003). Significant differences among groups were detected using Duncan's multiple rang test (1955). A value of $p$ $\leq 0.05$ was considered statistically significant.

\section{RESULTS}

Changes in femoral bone
parameters in different
experimental groups:

The OVX group showed the lowest femoral bone parameters tested $(\mathrm{p}<0.01)$ amongst all experimental groups except for the $\%$ of water content which was significantly higher $(p<0.01)$. However, the ratio between the non-organic (ash) to the organic component showed insignificant difference between all groups (table $1)$.

In OVX+ GHRP-6 treated group, no significant change $(p>0.05)$ was observed except, the bone length which was significantly $(p<0.05)$ higher when compared to the control group. Comparing the effects of GHRP-6 vs. estrogen, the bone length, weight, FFDW and the ash weight were significantly higher $(p<0.01)$ in the OVX+GHRP-6 group compared to the OVX+ estrogen group (table 1)

Regarding the BMD, the OVX group showed the lowest BMD ($20 \%$ ) between all groups. Both estrogen and GHRP-6 treated groups showed significantly higher BMD $(\mathrm{p}<0.01)$ with a value of $17.86 \%$ and $16.71 \%$ respectively as compared with the OVX non-treated group but, insignificantly different from the control level (table 2).

The lowest levels $(\mathrm{p}<0.01)$ of femoral calcium and phosphorus contents were observed in the OVX group. However, both estrogen and GHRP-6 treatments reversed the situation and caused significantly higher levels $(\mathrm{P}<0.01) \quad$ when compared with OVX non-treated group but insignificantly different from the control level (figure 1,2).

Changes in serum levels of calcium, phosphorus, ALP and ACP different experimental groups:

Serum calcium levels didn't change in all studied groups $(\mathrm{p}>0.05)$ compared with the control group. However, serum phosphorus concentration in the OVX group was significantly higher $(p<0.01)$ than the other groups (figure 3,4 ). 
Serum levels of ALP and ACP were highest $(\mathrm{p}<0.01)$ in OVX group. While estrogen treatment lowered significantly both phosphatases $(p<0.01)$ even below control levels, GHRP-6 treatment to OVX rats prevented any significant rise in ACP level. On the other hand, ALP levels were significantly lowered but not to the control level $(\mathrm{p}<0.01)$ (figure 5, $6)$.

Table (1): Changes in femoral bone tested parameters in different experimental groups $(\mathbf{M} \pm \mathbf{S E})$.

\begin{tabular}{|c|c|c|c|c|c|}
\hline Garameter & Control & OVX & $\mathrm{OVX}+\mathrm{E}$ & OVX+GHRP-6 & Sig \\
\hline Femur length (cm) & $3.10 \pm 0.04^{b}$ & $3.15 \pm 0.06^{b}$ & $3.06 \pm 0.05^{b}$ & $3.30 \pm 0.03^{\mathrm{a}}$ & $* *$ \\
\hline Bone Weight (g ) & $0.54 \pm 0.01^{\mathrm{ab}}$ & $0.49 \pm 0.01^{\mathrm{c}}$ & $0.53 \pm 0.01^{\mathrm{b}}$ & $0.57 \pm 0.01^{\mathrm{a}}$ & $* *$ \\
\hline Dry weight ( g) & $0.43 \pm 0.02^{\mathrm{a}}$ & $0.33 \pm 0.01^{\mathrm{b}}$ & $0.42 \pm 0.02^{\mathrm{a}}$ & $0.45 \pm 0.01^{\mathrm{a}}$ & $* *$ \\
\hline FFDW $(\mathrm{g})$ & $0.42 \pm 0.02^{\mathrm{ab}}$ & $0.33 \pm 0.01^{\mathrm{c}}$ & $0.41 \pm 0.01^{\mathrm{b}}$ & $0.45 \pm 0.003^{\mathrm{a}}$ & $* *$ \\
\hline Ash weight (g) & $0.27 \pm 0.01^{\mathrm{ab}}$ & $0.21 \pm 0.003^{c}$ & $0.27 \pm 0.01^{\mathrm{b}}$ & $0.29 \pm 0.01^{\mathrm{a}}$ & $* *$ \\
\hline $\begin{array}{l}\text { Organic matrix } \\
\text { weight }(\mathrm{g})\end{array}$ & $0.16 \pm 0.01^{\mathrm{a}}$ & $0.12 \pm 0.01^{\mathrm{b}}$ & $0.15 \pm 0.01^{\mathrm{a}}$ & $0.15 \pm 0.01^{\mathrm{a}}$ & $* *$ \\
\hline $\begin{array}{l}\text { Ratio of non- } \\
\text { organic to organic }\end{array}$ & $1.73 \pm 0.10$ & $1.86 \pm 0.13$ & $1.79 \pm 0.16$ & $2.01 \pm 0.15$ & NS \\
\hline $\begin{array}{l}\% \text { of non-organic } \\
\text { components }\end{array}$ & $50.02 \pm 0.99^{\mathrm{a}}$ & $42.91 \pm 0.79^{b}$ & $49.96 \pm 1.63^{\mathrm{a}}$ & $51.75 \pm 1.61^{\mathrm{a}}$ & $* *$ \\
\hline $\begin{array}{l}\% \text { of organic } \\
\text { components }\end{array}$ & $29.56 \pm 1.47^{\mathrm{a}}$ & $23.30 \pm 1.35^{\mathrm{b}}$ & $29.01 \pm 1.53^{\mathrm{a}}$ & $26.95 \pm 1.50^{\mathrm{a}}$ & $*$ \\
\hline$\%$ of water content & $20.42 \pm 1.65^{b}$ & $33.07 \pm 1.68^{\mathrm{a}}$ & $21.01 \pm 1.49^{\mathrm{b}}$ & $21.69 \pm 0.64^{b}$ & $* *$ \\
\hline
\end{tabular}

$\mathrm{a}, \mathrm{b}$ and $\mathrm{c}=$ in the same horizontal row, means with different superscripts are significantly different $(\mathrm{P}<0.05)$.
NS: not significant.
$* \mathrm{P}<0.05$
$* * \mathrm{P}<0.01$

$\mathrm{N}$ is the number of rats in each group.

$(\mathrm{M} \pm \mathrm{SE})=$ mean \pm standard error.

Table (2): Percentage changes in BMD in different experimental groups $(M \pm$ SE)

\begin{tabular}{|c|c|c|c|}
\hline Groups $\quad \mathrm{N}=10$ & $\begin{array}{l}\text { BMD } \\
\left(\mathrm{gm} / \mathrm{cm}^{3}\right)\end{array}$ & $\begin{array}{l}\text { Percentage changes } \\
\text { from OVX }\end{array}$ & $\begin{array}{l}\text { Percentage changes } \\
\text { from control }\end{array}$ \\
\hline Control & $3.74 \pm 0.088^{\mathrm{a}}$ & $20 \%$ & -------- \\
\hline OVX & $2.99 \pm 0.046^{\mathrm{b}}$ & ------- & $-20 \%$ \\
\hline $\mathrm{OVX}+\mathrm{E}$ & $3.64 \pm 0.072^{\mathrm{a}}$ & $17.86 \%$ & $-2.7 \%$ \\
\hline OVX + GHRP-6 & $3.59 \pm 0.088^{\mathrm{a}}$ & $16.71 \%$ & $-3.9 \%$ \\
\hline
\end{tabular}

$\mathrm{a}, \mathrm{b}$ and $\mathrm{c}=$ in the same vertical row, means with different superscripts are significantly different $(\mathrm{P}<0.01)$. 


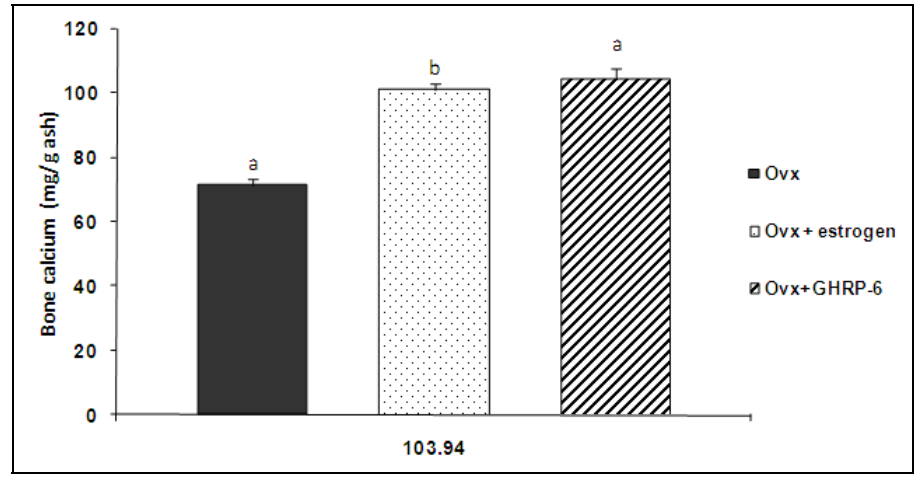

Fig (1): Changes in femoral bone calcium content in different studied groups $(\mathrm{M} \pm \mathrm{SE})$

$\mathrm{a}$ and $\mathrm{b}$ means that columns with different superscripts are significantly different $(P<0.05)$

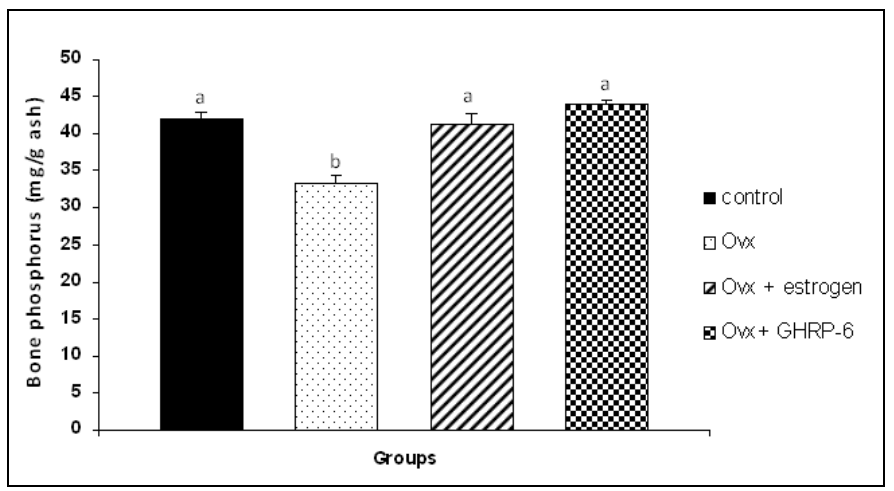

Fig 2. Changes in femoral bone phosphorus content in different studied groups $(\mathrm{M} \pm \mathrm{SE})$

$\mathrm{a}$ and $\mathrm{b}$ means that columns with different superscripts are significantly different $(P<0.05)$.

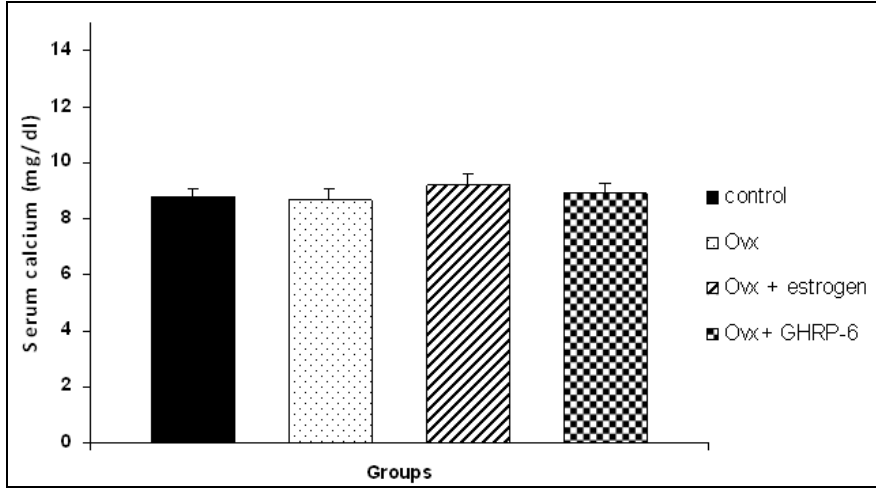

Fig 3. Serum calcium levels in different experimental groups $(M \pm S E)$ 


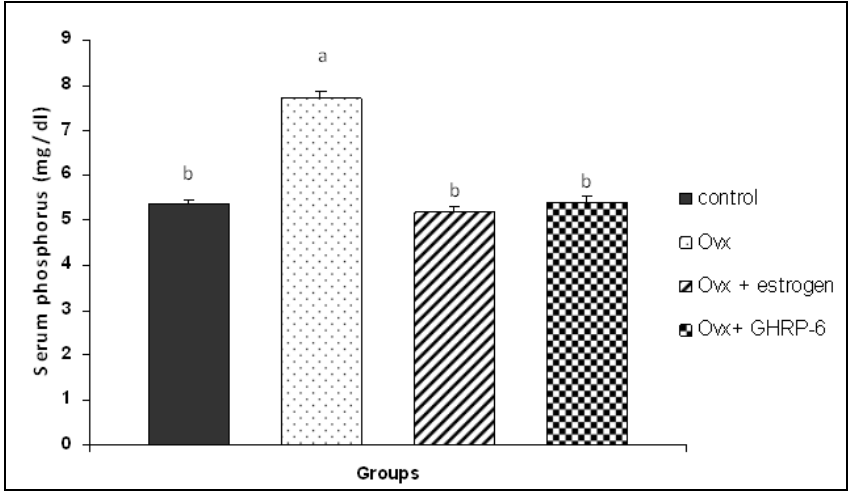

Fig 4. Serum phosphorus level in different experimental groups $(M \pm S E)$ a and $b$ means that columns with different superscripts are significantly different $(P<0.05)$.

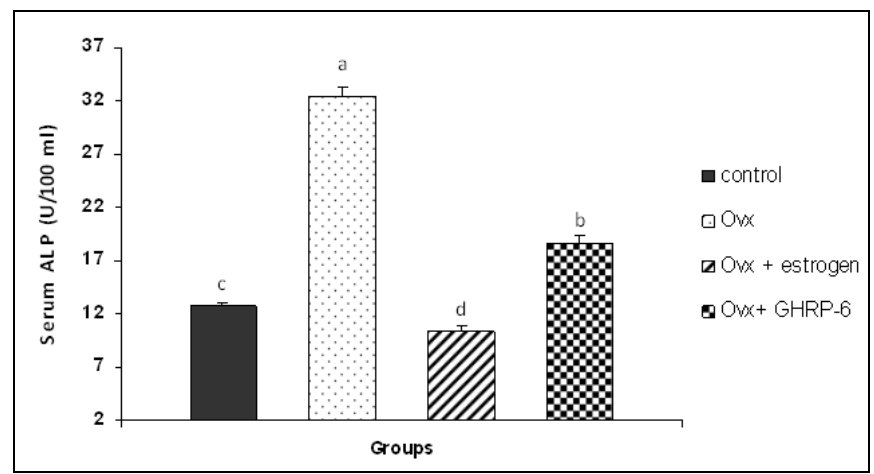

Fig 5. Serum alkaline phosphatase level in different experimental groups $(\mathbf{M} \pm \mathrm{SE})$.

a, b, cand d means that columns with different superscripts are significantly different $(P<0.05)$.

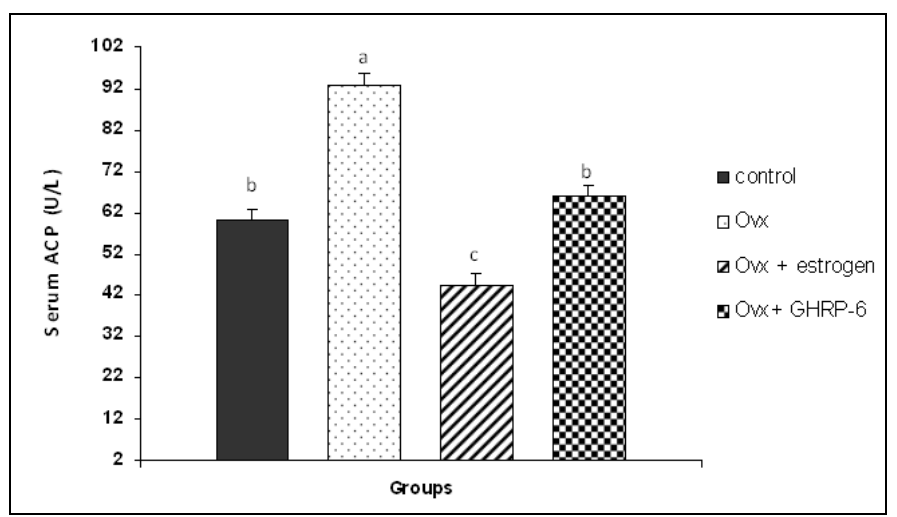

Fig 6. Serum acid phosphatase level in different experimental groups $(\mathrm{M} \pm \mathrm{SE})$.

$\mathrm{a}, \mathrm{b}$ and $\mathrm{c}$ means that columns with different superscripts are significantly different $(P<0.05)$. 


\section{DISCUSSION}

Prevention of bone loss in postmenopausal period is an effective strategy to reduce the incidence of osteoporotic bone fractures therefore, the aim of the present study was to evaluate and compare the preventive effects of estrogen and GHRP-6 treatments on femoral bone loss in ovariectomized albino rats by studying the changes in femoral bone mass, density and mineral content and also serum parameters including bone turnover markers (ALP and ACP) as well as serum calcium and phosphorus concentrations.

Ovariectomy closely mimics the human postmenopausal state. Endogenous estrogen levels are significantly reduced and the skeleton undergoes an increase in bone turnover, followed by accelerated bone loss and reductions in bone mineral at several skeletal sites ${ }^{[7]}$. The proximal femur in humans and rats share many histoanatomic similarities. Clinically, femoral neck is the most important site of fracture in humans so, femurs of OVX rats may be a more clinically relevant sample site than other skeletal sites ${ }^{[31]}$.

Estrogen supplementation attenuated successfully the OVXinduced bone loss evidenced by the significantly higher femoral bone mass and preserved the femoral BMD being $17.86 \%$ higher than the OVX non-treated rats. Wang et al. ${ }^{[32]}$ reported that the stimulatory effect of estrogen on bone density in OVX rats is mediated by up-regulating the expression of osteoprotegerin (OPG); a regulatory protein released from osteoblasts which acts on osteoclasts to suppress the osteoclast-mediated bone resorption and favors bone formation $^{[33]}$. Moreover, Nakamura et al. ${ }^{[34]}$ proved that estrogen withdrawal may prolong the life span of osteoclasts which in turn might be the cause of bone loss. In light of these findings, it is likely to say that estrogen dampens the process of bone resorption rather than promoting bone synthesis.

GHRP-6 injection was also successful in preventing OVXinduced bone loss as it was able to preserve femoral BMD which was $16.71 \%$ higher than the OVX nontreated group with significantly higher levels of all femoral bone parameters including femoral bone calcium and phosphorus contents. Similar findings were observed by Sibilia et al. ${ }^{[35]}$ who reported that the GHS; Hexarelin completely prevented the development of osteopenia in gonadectomized rats as proved by the stability in both BMD and BMC values at femoral metaphysis and lumber vertebra. Fukushima and colleagues $^{[36]}$ also showed that administrating peripheral ghrelin, a natural GHS, promoted bone formation in vivo when given to rodents over a 4 week period and demonstrated an increase in BMD. Therefore, these findings raises the possibility that growth hormone is critical for keeping bone mass and its deficiency could be involved in the pathogenesis of osteoporosis ${ }^{[15,37]}$.

The femurs lengths were also significantly higher in the OVX + GHRP-6 group than all other studied groups, and this finding is in 
agreement with Svensson et al. ${ }^{[15]}$. It might be due to linear bone growth derived from the growth plate and it could be explained by the fact that the growth plates in rats first begin to close when the rats are very old ${ }^{[38]}$. For this reason, most studies have found a small stimulatory effect of $\mathrm{GH}$ on longitudinal bone growth in adult rats ${ }^{[15,12]}$.

Regarding bone turnover markers (ALP and ACP), ovariectomy showed significantly higher levels when compared with the control group. This finding is in line with Rahnama and Swiatkowski $^{[39]}$ who reported that hypoestrogenism after ovariectomy caused a characteristic increase in bone turnover markers in experimental rats. Also, it matches with Al-Sowyan and Mahmoud ${ }^{[40]}$ who demonstrated that lacking of the inhibitory action of estrogen on osteoclasts caused the increase in ACP activity and consequently, an increase in bone resorption. Simultaneously with intensification of resorption process, bone formation process was also increased by enhancement of osteoblast activity which results in increasing ALP activity.

Estrogen supplementation to OVX rats reversed the condition and lowered significantly serum levels of both phosphatases even below the control level. It could be attributed to the direct suppressing effect of estrogen on receptor activator of nuclear factor- $\kappa \mathrm{B}$ ligand (RANKL)induced osteoclast differentiation and thus inhibiting bone resorption with subsequent decrease in serum ACP. Serum ALP level is also lowered secondary to reduced bone formation $^{[39,40]}$.

Interestingly, GHRP-6 treatment to OVX rats prevented any significant rise in ACP level indicating suppression of bone resorption. On the other hand, ALP levels were significantly lowered but not to the control level indicating enhanced bone formation. This positive shift in the balance between bone formation and resorption towards the favor of bone formation could account for the protective effects of GHRP-6 on OVX-induced bone loss.

In line with our results, Svensson et al. ${ }^{[14]}$ reported that the GHS; MK677 treatment elicited a rapid induction of markers of bone turnover whereas the increase in markers of bone formation was more marked at the end of the study. Moreover, Fukushima et al. ${ }^{[36]}$ reported that the natural GHS; ghrelin directly stimulated osteoblast proliferation and differentiation and alkaline phosphatase activity.

The most reasonable interpretation for the anabolic action of GHRP-6 on bone may be related in part to its welldocumented GH-releasing activity and/or a direct stimulatory effect on osteoblasts as it has been demonstrated that primary osteoblasts and osteoblastic cell lines in various species contain GHS-R1a receptors $^{[41]}$.

Unexpectedly, serum calcium concentration did not show any significant change after 6 weeks of OVX. Similar findings were reported by Arshad et al. ${ }^{[42]}$ and Zhang et al. ${ }^{[43]}$. It could be explained by the fact that homeostatic mechanisms were able to maintain serum calcium level 
for 4 to 6 weeks despite $\mathrm{OVX}^{[31]}$. It seems that estrogen deficiency increases the sensitivity of bone to parathyroid hormone (PTH) and other resorption-inducing agents which further enhance the resorption defect $^{[44]}$. In turn, a compensatory increase in urinary calcium excretion $^{[45]}$ and decreases in intestinal calcium absorption ${ }^{[46]}$ takes place to prevent the resultant skeletal outflow of calcium into the extracellular fluids from producing hypercalcemia.

As regards serum phosphorus, OVX induced a significant rise in serum phosphorus concentration compared with the control rats. Similar studies were reported by Gopala et al. ${ }^{[4]}$ and Kavuncu et al. ${ }^{[48]}$. They found that serum phosphorus levels increased from the sixth day following OVX as a consequence of increased renal tubular reabsorption. This OVXinduced rise in serum phosphorus level could be attributed to the selective inhibitory effect of estrogen on sodium phosphate co-transport by direct interaction with estrogen receptors in proximal tubular cells and hence, increased proximal phosphate reabsorption $^{[49,50]}$.

In conclusion, the present study clearly demonstrated that GHRP-6 exerts a protective effect against OVX-induced bone loss in female albino rats mainly via preservation of femoral bone mass, density and mineral content as well as a positive shift between bone resorption and bone formation for the benefit of increased bone formation.

Indeed, theses results could open the way for GHRP-6 to be a potentially substituent for estrogen in menopausing osteoporotic females with no adverse effects.

\section{REFERENCES}

1. Nakamura H (2007): Morphology, function and differentiation of bone cells. J.Hard Tiss. Biol., 16(1): 15-22.

2. Chesnut III CH, Skag A, Christiansen C, Recker R, Stakkestad JA, Hoiseth A, Felsenberg D, Huss H, Gilbride J, Schimmer RC, Delmas PD (2004): Effects of oral ibandronate administered daily or intermittently on fracture risk in postmenopausal osteoporosis. J. Bone Miner. Res., 19(8): 12411249.

3. Rochira V, Balestrieri A, Madeo B, Zirilli L, Granata ARM, Carani C (2006): Osteoporosis and male agerelated hypogonadism: role of sex steroids on bone pathophysiology. Eur. J. Endocrinol., 154(1): 175-185.

4. Hidaka S, Okamoto Y, Uchiyama S, Nakatsuma A, Hashimoto K, Ohnishi ST, Yamaguchi M (2006): Royal jelly prevents osteoporosis in rats: beneficial effects in ovariectomy model and in bone tissue culture model. Evid Based Complement Alternat. Med., 3(3): 339-348.

5. Compston JE (2001): Sex steroids and bone. Physiol. Rev., 81(1): 419-447.

6. Zengin A, Zhang L, Herzog $\mathbf{H}$, Baldock PA, Sainsbury A (2010): Neuropeptide Y and sex hormone interactions in humoral 
and neuronal regulation of bone and fat. Trends Endocrinol. Metab., 21(7): 411-418

7. Egermann M, Goldhahn J, Schneider E (2005): Animal models for fracture treatment in osteoporosis. Osteoporos. Int., 16(2): S1 29-38.

8. Phillips A, Ebbutt A, France L (2000): The international conference on harmonization guideline "Statistical Principles for Clinical Trials": Issues in applying the guideline in practice. Drug Inf. J., 34(2): 337-348.

9. Anderson GL, Limacher $M$, Assaf AR, Bassford T, Beresford SA, Black $H$, Bonds D, Brunner R, Brzyski R, Caan $B$ et al. (2004): Effects of conjugated equine estrogen in postmenopausal women with hysterectomy: the Women's Health Initiative randomized controlled trial. JAMA 291(14): 1701-1712.

10. Geary $N$ and Asarian L (2001): Estradiol increases glucagon's satiating potency in ovariectomized rats. Am. J. Physiol. Regul. Integr. Comp. Physiol., 281(4): R1290-R1294.

11. Bouxsein ML (2003): Mechanisms of osteoporosis therapy: a bone strength perspective. Clinical Cornerstone Suppl.,2: S13-S21.

12. Svensson J, Lall S, Dickson SL, Bengtsson BÅ, Rømer J, Ahnfelt-Rønne I, Ohlsson C, Jansson JO (2001): Effects of growth hormone and its secretagogues on bone. Endocrine 14: 63-66.
13. Fanciulli G, Delitala A, Delitala G (2009): Growth hormone, menopause and ageing: no definite evidence for 'rejuvenation' with growth hormone. Hum. Reprod. Update 15(3): 341-358.

14. Svensson J, Ohlsson C, Jansson JO, Murphy G, Wyss D, Krupa D, Cerchio K, Polvino W, Gertz B, Baylink D, Mohan S, Bengtsson BA (1998): Treatment with the oral growth hormone secretagogue MK-677 increases markers of bone formation and bone resorption in obese young males. J. Bone Mineral Res., 13(7): 1158-1166.

15. Svensson J, Lall S, Dickson SL, Bengtsson BÅ, Rømer J, Ahnfelt-Rønne I, Ohlsson C, Jansson JO (2000): The Growth Hormone (GH) secretagogues Ipamorelin and GH-releasing peptide- 6 increase bone mineral content in adult female rats. J. Endocrinol., 165: 569-577.

16. Cordido F, Isidro ML, Nemiña R, Sangiao-Alvarellos S (2009): Ghrelin and growth hormone secretagogues, physiological and pharmacological aspect. Curr. Drug Discov. Technol., 6(1): 3442.

17. Shimizu N, Yamaguchi M, Uesu K, Goseki T, Abiko Y (2000): Stimulation of prostaglandin $\mathrm{E}_{2}$ and interleukin-1ß production from old rat periodontal ligament cells subjected to mechanical stress. J. Gerontol. A Biol. Sci. Med. Sci., 55(10): B489-B495.

18. Car/Lac standard procedures (2003): Gonadectomy in rats and 
mice UCSF-animal care and use program, pp 76-84.

19. Schmidt IU, Wakley GK, Turner RT (2000): Effects of estrogen and progesterone on tibia histomorphometry in growing rats. Calcif. Tissue Int., 67(1): 47-52.

20. Corns CM and Ludman CJ (1987): Some observations on the nature of the calciumcresolphthalein complexone reaction and its relevance to the clinical laboratory Ann. Clin. Biochem., 24(Pt.4): 345-351.

21. Thomas L (1998): Clinical laboratory diagnostics. $1^{\text {st }}$ edition. Frankfurt: TH-Books Verlagsgesellschaft; Chaft; $p$. 241-247.

22. Kind PRN and King EJ (1954): Estimation of plasma phosphatase by determination of hydrolyzed phenol with amino-antipyrine. J. Clin. Path., 7(4): 322-326.

23. Pickering RG and Pickering CE (1978): Studies of rat alkaline phosphatase. Archives of Toxicology 39(4):267 - 287.

24. 24-Zhang $B$ and Coon $C N$ (1992): Nutrition Institute on minerals. Chapter 7 Practical Applications. National Feed Ingredient Association, Chicago, IL, pp 64-77.

25. Keenan MJ, Hegsted M, Jones KL, Delany JP, Kime JC, Melancon LE, Tulley RT, Hong KD (1997): Comparison of bone density measurement techniques: DXA and Archimedes' principle. J. Bone Miner. Res., 12(11): 1903-1907.

26. Brzoska MM, MoniuszkoJakoniuk J, Jurczuk M,
Galazyn-Sidorczuk

M, Rogalska J (2001): The effect of zinc supply on cadmium-induced changes in the tibia of rats. Food Chem. Toxicol., 39: 729-737.

27. Watkins KL and Southern LL (1992): Effect of dietary sodium zeolite A and graded levels of calcium and phosphorous on growth, plasma and tibia characteristics of chicks. Poult. Sci., 71: 1048-1058.

28. Zhang B and Coon CN (1997): The relationship of various tibia bone measurements in hens. Poult. Sci., 76(12): 1698-1701.

29. Miles PH, Wilkinson NS, McDowell LR (2001): Analysis of minerals for animal nutrition research. $3^{\text {rd }}$ edition Dept Anim. Sci, Univ. Florida, Gainesville, pp 342-354.

30. Masse PG, Rimnac CM, Yamauchi M, Coburn SP, Rucker RB, Howell DS, Boskey AL (1996): Pyridoxine deficiency affects biomechanical properties of chick tibial bone. Bone 18(6): 567-574.

31. Li XX., Hara I, Matsumiya T (2002): Effects of osthole on postmenopausal osteoporosis using ovariectomized rats: Comparison to the effects of estradiol. Biol. Pharm. Bull., 25(6): 738-742.

32. Wang $Q$, Wang KZ, Dang XQ, Shi ZB, Pei XW, Bai CY, Jia XW (2006): Effect of estrogen on osteoprotegerin, osteoclast differentiation factor and macrophage colony stimulating factor mRNA Expressions in ovariectomized rat bone tissue. 
Nan Fang Yi Ke Da Xue Xue Bao 26(4): 532-534.

33. Bar-Shavit $Z$ (2007): The osteoclast: a multinucleated, hematopoietic-origin, boneresorbing osteoimmune cell. J. Cell. Biochem., 102(5): 11301139.

34. Nakamura T, Imai Y, Matsumoto T, Sato S, Takeuchi K, Igarashi K, Harada Y, Azuma Y, Krust A, Yamamoto Azuma Y, Krust A, Yamamoto Y, Nishina $H$, Takeda S, Takayanagi H, Metzger D, Kanno J, Takaoko K, Martin TJ, Chambon P, Kato S (2007): Estrogen prevents bone loss via estrogen receptor alpha and induction of Fas ligand in osteoclasts. Cell 130(5): 811-823.

35. Sibilia V, Cocchi D, Pagani F, Lattuada N, Moro GL, Pecile A, Rubinacci A, Muler EE, Netti C (1999): Hexarelin, a growth hormone-releasing peptide, counteracts bone loss in gonadectomized male rats. Growth Hormone \& IGF Res., 9(4): 219-227.

36. Fukushima N, Hanada $\mathbf{R}$, Teranishi H, Fukue Y, Tachibana $\mathbf{T}$, Ishikawa $\mathbf{H}$, Takeda S, Takeuchi Y, Fukumoto $\mathbf{S}$, Kangawa $\mathbf{K}$, Nagata K, Kojima M (2005): Ghrelin directly regulates bone formation. J. Bone Miner. Res., 20(5): 790-798.

37. Sibilia V, Cocchi1 D, Villa N, Lattuada A, Soglian A, Rubinacci A, Muller EE, Pecile A, Netti C (2002): Bone effects of hexarelin, a GH-releasing peptide, in female rats: influence of estrogen milieu. Eur. J. Endocrinol., 146 (1): 855-862.

38. Ohlsson C, Bengtsson BÅ, Isaksson OGP, Andreassen TT, Slootweg MC (1998): Growth hormone and bone. Endoc. Rev., 19: 55-79.

39. Rahnama $M$ and Świątkowski W (2002): Effect of ovariectomy on biochemical markers of bone turnover (ALP, ACP) and calcium content in rat mandible and teeth. Bull. Vet. Inst. Pulawy 46: 281-287.

40. Al-Sowyan NS, Mahmoud NH (2010): The effect of folic acid supplementation on osteoporotic markers in ovariectomized rats. Egypt. Acad. J Biolog. Sci., 2(2): 11-20.

41. Van Leeuwen H (2010): Ghrelin and ghrelin signaling in bone metabolism. Endocrine Abstracts 21: S2.3.

42. Arshad M, Sengupta S, Sharma S, Ghosh R, Sawlani V, Singh M.M. (2004): In Vitro antiresorptive activity and prevention of ovariectomy-induced osteoporosis in female SpragueDawley rats by o rmeloxifene, a selective estrogen receptor modulator. J. Steroid Biochem. Mol. Biol., 91(1-2): 67-78.

43. Zhang $Y$, Lai WP, Leung PC, Wu CF, Wong MS (2007): Short- to Mid-term effects of ovariectomy on bone turnover, bone mass and bone strength in rats. Biol. Pharm. Bull., 30(5): 898-903.

44. Shen V, Birchman R, Wu DD, Lindsay $R$ (2000): Skeletal effects of parathyroid hormone infusion in ovariectomized rats 
with or without estrogen repletion. J. Bone Miner. Res., 15: 740-746.

45. O'Loughlin PD and Morris HA (2003): Oophorectomy acutely increases calcium excretion in adult rats. J. Nutr., 133(7): 2277 2280

46. Ku SK, Lee HS, Lee JH (2004): Changes of gastrointestinal argyrophil endocrine cells in the osteoporotic SD rats induced by ovariectomy. J. Vet. Sci., 5(3): 183-188.

47. Gopala KV, Arunakaran J, Govindarajulu P, Srinivasan N (2003): Effects of estradiol and progesterone on vertebral collagen, glycosaminoglycans and phosphatases in ovariectomized adult rats. Horm. Metab. Res., 35(3): 137-141.
48. Kavuncu V, Sahin S, Baydas G, Ilhan N, Ozercan I, Yasar A, Pekkutucu I, Ozercan R (2003): A comparison of estrogen and two different doses of calcitonin in ovariectomized rats. Yonsei. Med. J., 44(3): 508-516.

49. Beers KW, Thompson MA, Chini EN, Dousa TP (1996): Beta-estradiol inhibits $\mathrm{Na}^{+2}-\mathrm{P}(\mathrm{i})$ cotransport across renal brush border membranes from ovariectomized rats. Biochem. Biophys. Res. Commun., 16; 221(2): 442-445.

50. Dick IM, Devine A, Beilby J, Prince RL (2005): Effects of endogenous estrogen on renal calcium and phosphate handling in elderly women. Am. J. Physiol. Endocrinol. Metab., 288: E430E435. 


\section{البيتيد السداسي المحفز لهرمون النمو: تأثير وقائي محتمل ضد هشاثة العظام

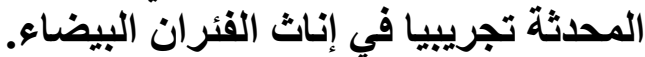

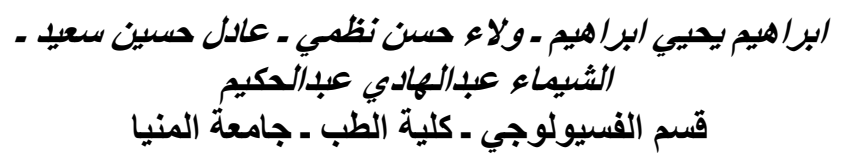

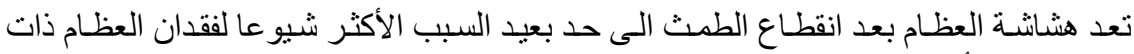

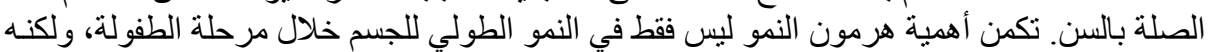

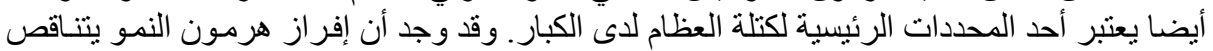

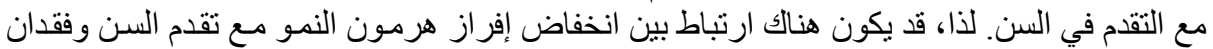

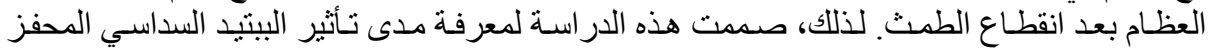

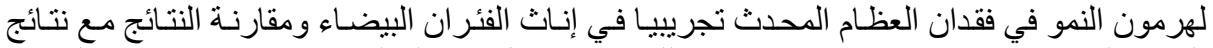

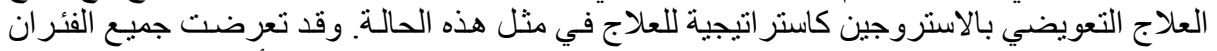

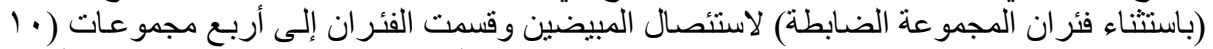

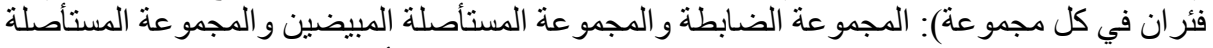

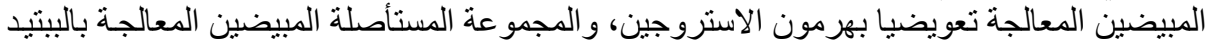

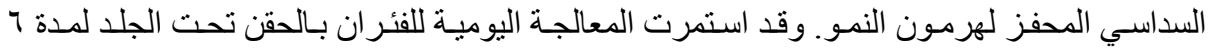

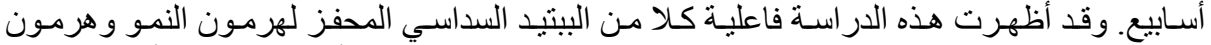

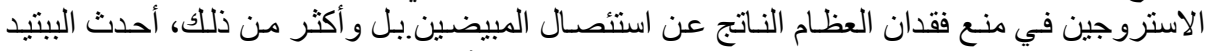

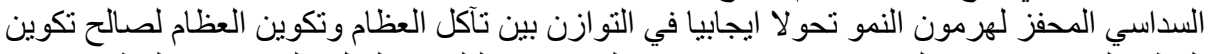

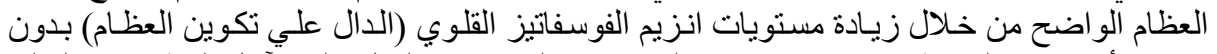

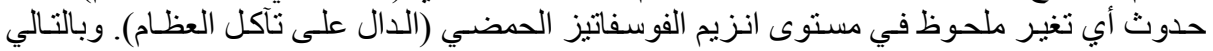

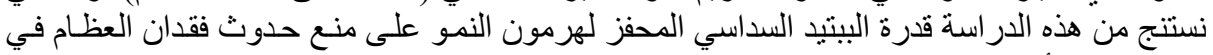

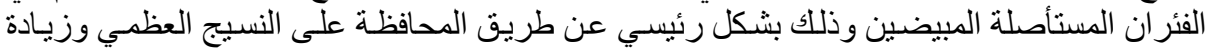

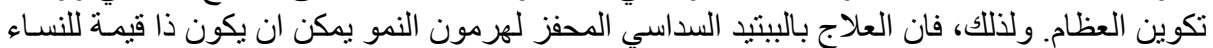

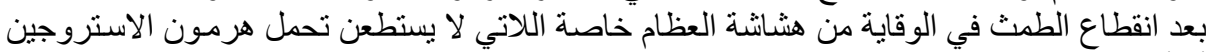
أو أكثر عرضة لمضاع الطفاته.

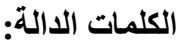

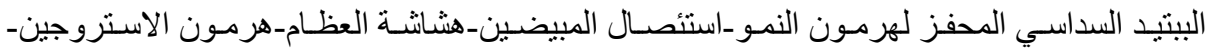

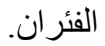

